\title{
Inhibition of the terminal differentiation of odontoblasts and their transdifferentiation into osteoblasts in Runx2 transgenic mice*
}

\author{
Toshihiro Miyazaki ${ }^{1}$, Naoko Kanatani ${ }^{1}$, Satoshi Rokutanda ${ }^{1,2}$, Carolina Yoshida ${ }^{1}$, \\ Satoru Toyosawa ${ }^{3}$, Reiko Nakamura ${ }^{4}$, Shinji Takada ${ }^{4}$, and Toshihisa Komori ${ }^{1}$ \\ ${ }^{1}$ Department of Cell Biology, Unit of Basic Medical Sciences, and ${ }^{2}$ Department of Oral and Maxillofacial Surgery, \\ Unit of Translational Medicine, Nagasaki University Graduate School of Biomedical Sciences, Nagasaki; and \\ ${ }^{3}$ Department of Oral Pathology, and ${ }^{4}$ Department of Orthodontics and Dentofacial Orthopedics, Osaka University \\ Faculty of Dentistry, Osaka, Japan
}

Summary. Runx 2 is an essential transcription factor for bone and tooth development whose function in odontoblast differentiation remains to be clarified. To pursue this issue, we examined tooth development in Runx2 transgenic mice under the control of Collal promoter (Tg(Colla1-Runx2) mice). Endogenous Runx2 protein was detected in the nuclei of preodontoblasts, immature odontoblasts, mesenchymal cells in the dental sac, and osteoblasts, while transgene expression was detected in odontoblasts and osteoblasts. Odontoblasts in $\mathrm{Tg}$ (Coll aIRunx2) mice lost their columnar shape and dentin was deposited around the odontoblasts, which were cuboid or flat in shape. The dentin in $\operatorname{Tg}($ Collal-Runx2) mice was thin and possessed lacunae that contained odontoblasts and bone canaliculi-like structures, while predentin and

Received May 7, 2008

* This work was supported in part by a Grant-in-Aid for
Scientific Research from the Japan Society for the Promotion
of Science (19592120) and the President's Discretionary Fund
of Nagasaki University, Japan.

Address for correspondence: Prof. Toshihisa Komori, MD, PhD, Department of Cell Biology, Unit of Basic Medical Sciences, Nagasaki University Graduate School of Biomedical Sciences, 1-7-1 Sakamoto, Nagasaki 852-8588, Japan

Tel: +81-95-819-7630, Fax: +81-95-819-7633

E-mail: komorit@nagasaki-u.ac.jp dentinal tubules were absent. We examined the expression of dentin matrix protein genes, Collal and dentin sialophosphoprotein (DSPP), by in situ hybridization, and dentin matrix proteins, osteocalcin, osteopontin, and dentin matrix protein 1 (DMP1) as well as an intermediate filament, nestin, by immunohistochemistry to characterize odontoblasts in $\mathrm{Tg}(\mathrm{Colla1}-\mathrm{Runx} 2)$ mice. Results showed Collal expression was down-regulated, DSPP expression was lost, and nestin expression was severely decreased in the odontoblasts of $\mathrm{Tg}(\mathrm{Colla1}-\mathrm{Runx} 2)$ mice. Further, the expressions of osteocalcin, osteopontin, and DMP1 were up-regulated in odontoblasts, although the upregulation of osteocalcin expression was transient. These findings indicate that Runx 2 inhibits the terminal differentiation of odontoblasts, and that Runx 2 induces transdifferentiation of odontoblasts into osteoblasts forming a bone structure. Thus, Runx2 expression has to be downregulated during odontoblast differentiation to acquire full odontoblast differentiation for dentinogenesis.

\section{Introduction}

Dentinogenesis begins when outer cells from the dental papilla, which is derived from neural crest cells, are induced to differentiate into odontoblasts. Odontoblasts start their polarization while elongating and developing synthesis organelles, assume a tall columnar shape with an apical process, and establish a continuous single layer with a clear epithelial appearance 
(Arana-Chavez and Massa, 2004). Odontoblasts synthesize and secret type I collagen and noncollagenus dentin matrix proteins, including dentin sialophosphoprotein (DSPP), which is a large parental protein that subsequently suffers cleavage to originate dentin sialoprotein (DSP) and dentin phosphoprotein (DPP), dentin matrix protein 1 (DMP1), and a small amount of four noncollagenous proteins (osteopontin, bone sialoprotein, osteonectin, and osteocalcin) that are abundantly synthesized and secreted by osteoblasts (Linde and Goldberg, 1993; Butler and Ritchie, 1995). Further, DMP1 is synthesized and secreted by osteocytes as well as odontoblasts (Toyosawa et al., 2001, 2004).

Runx2, a transcription factor that belongs to the Runx family, is essential for osteoblast differentiation (Komori et al., 1997; Otto et al., 1997). The formation of tooth germ in Runx2-deficient mice terminates at the cap stage, and the differentiation of ectomesenchymal cells in dental papilla to odontoblasts is blocked, indicating that Runx 2 is an essential transcription factor for odontogenesis (D'Souza et al., 1999; Aberg et al., 2004). Runx2 expression is upregulated in the condensed dental mesenchyme but downregulated in differentiated odontoblasts during cytodifferentiation (Bronckers et al., 2001; Yamashiro et al., 2002; Chen et al., 2005). Since tooth germs in Runx2-deficient mice lack differentiated odontoblasts and the mice die soon after birth, the function of Runx 2 in the process of odontoblast differentiation remains to be clarified.

We previously generated Runx2 transgenic mice under the control of $2.3 \mathrm{~kb}$ Collal promoter $(\mathrm{Tg}(\mathrm{Coll}$ a1-Runx2) mice) to examine the function of Runx 2 in the late stage of osteoblast differentiation (Liu et al., 2001; Kanatani et al., 2006). In Tg(Colla1-Runx2) mice, osteoblast differentiation in the late stage was inhibited; the expression of osteopontin, which is highly expressed in immature osteoblasts, was upregulated; the expression of osteocalcin, which is highly expressed in mature osteoblasts, was downregulated; and osteocyte numbers were severely reduced (Liu et al., 2001; Geoffroy et al., 2002; Kanatani et al., 2006). As the $2.3 \mathrm{~kb}$ Collal promoter specifically drives transgene expression to osteoblasts and odontoblasts (Rossert et al., 1995; Liu et al., 2001) and Runx2 expression is downregulated in mature odontobasts (Bronckers et al., 2001; Yamashiro et. al., 2002; Chen et al., 2005), we examined the effects of the sustained expression of Runx2 in odontoblasts using $T g(\operatorname{Collal}$-Runx2) mice to reveal the function of Runx 2 in odontoblast differentiation.

\section{Materials and Methods}

\section{Transgenic mice}

$\operatorname{Tg}($ Colla1-Runx2) mice and $\operatorname{Tg}($ Colla1-lacZ) mice were generated as previously described (Liu et al., 2001). $\beta$ galactosidase activity was detected as described (Ueta $e t$ al., 2001). Transgenic lines were maintained in a $\mathrm{B} 6 \mathrm{C} 3 \mathrm{H}$ F1 background. Prior to the study, all experiments were reviewed and approved by the Animal Care and Use Committee of Nagasaki University Graduate School of Biomedical Sciences.

\section{Histological analysis}

For histological analysis, 0-, 3-, 7-, 14-, 21- and 28-dayold mice were used for examination. After anesthetization with an intraperitoneal injection of sodium pentobarbital, they were perfused with $4 \%$ paraformaldehyde in $0.05 \mathrm{M}$ cacodylate buffer (pH7.4) for light microscopic analysis, or with $2 \%$ glutaraldehyde $-2.5 \%$ paraformaldehyde in $0.05 \mathrm{M}$ cacodylate buffer $(\mathrm{pH} 7.4)$ for ultrastructural analysis. Dissected mandibles were further immersed in the same fixatives for $24 \mathrm{~h}$ at $4^{\circ} \mathrm{C}$ and decalcified in $5 \%$ EDTA (pH7.4) for 3 days to 4 weeks at $4{ }^{\circ} \mathrm{C}$. For light microscopic analysis, tissues were embedded in paraffin. Sections $(4 \mu \mathrm{m})$ were stained with hematoxylin and eosin or processed for in situ hybridization and immunohistochemical analysis as described below. Sections were treated for silver impregnation staining based on the method by Kurazaki et al. (2000) to discern canalicular structures. For ultrastructural analysis, tissues were post-fixed with osmium tetraoxide in $0.05 \mathrm{M}$ cacodylate buffer (pH7.4) and embedded in Epon-Araldite resin. Ultrathin sections were stained with $2 \%$ uranyl acetate and Reynold's lead citrate and examined using a Hitachi H-7100 electron microscope.

\section{In situ hybridization}

Digoxigenin-11-UTP-labeled single-stranded RNA probes were prepared using a DIG RNA labeling kit (Roche Biochemica, Mannheim Germany), according to the manufacturer's instructions. A $0.32 \mathrm{~kb}$ fragment of mouse Collal cDNA (Inada et al., 1999) and a $0.42 \mathrm{~kb}$ fragment of mouse DSPP cDNA were used to generate antisense and sense probes. Hybridization was carried out as described (Inada et al., 1999). In situ hybridization using the sense probes showed no significant signals (data not shown). 
Fig. 1. Expression patterns of endogenous Runx 2 protein. Runx 2 expression patterns in the lower first molars of 3-day-old (a, b) and 1-week-old (c, d) wild-type mice were examined by immunohistochemistry. Boxed regions in a and $\mathrm{c}$ are magnified in $\mathrm{b}$ and d, respectively. Runx2 is endogenously localized in the nuclei of preodontoblasts (a, short arrows), young odontoblasts (b, arrows), dental sac cells, and osteoblasts in tooth germs. It is also found transiently in the nuclei of ameloblasts in the coronal regions at 1 week of age (d, arrowheads). Ab: ameloblasts, D: dentin, Dp: dental papilla, Ds: dental sac, E: enamel, Ob: odontoblasts. Bars $=100 \mu \mathrm{m}$ (a), $20 \mu \mathrm{m}$ (b), $200 \mu \mathrm{m}(\mathrm{c}), 50 \mu \mathrm{m}(\mathrm{d})$
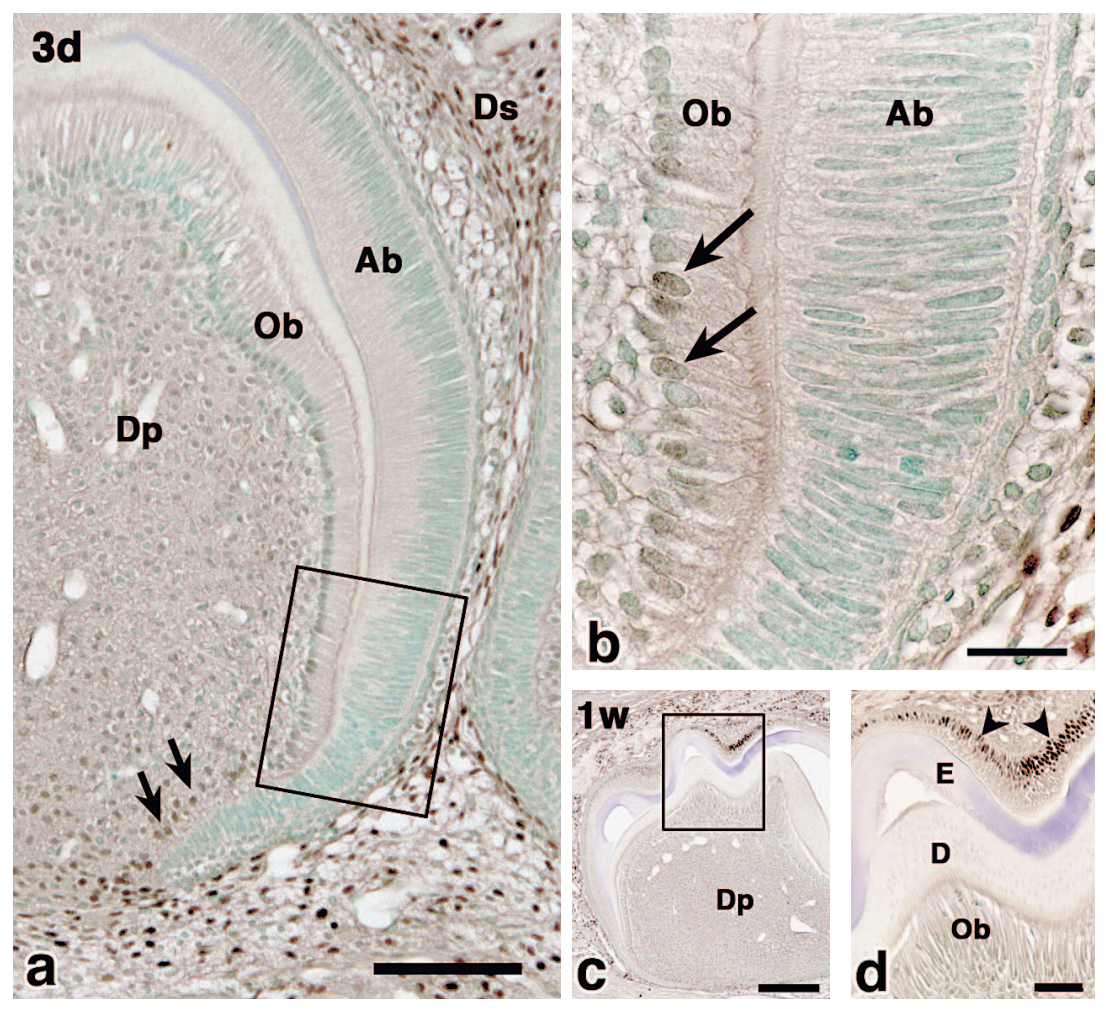

\section{Immunohistochemistry}

Immunohistochemical staining was carried out for Runx2, nestin, osteocalcin, osteopontin, and DMP1. A monoclonal mouse anti-Runx2 antibody (Medical Biological Laboratories Co., Ltd., Nagoya), monoclonal mouse anti-nestin antibody (Chemicon International Inc., CA, USA), polyclonal rabbit anti-mouse osteocalcin antibody (Takara Bio Inc., Shiga), polyclonal rabbit anti-mouse osteopontin antibody (Immuno-Biological Laboratories Co., Ltd., Gunma) and polyclonal rabbit anti-DMP1 antibody (Toyosawa et al., 2004) were used as primary antibodies at dilutions of 1:100, 1:100, 1:1000, 1:50 and 1:1000, respectively. As negative controls, normal mouse IgG (Immuno-Biological Laboratories Co., Ltd.) for Runx2 and nestin, and normal rabbit IgG (ImmunoBiological Laboratories Co., Ltd.) for osteocalcin, osteopontin, and DMP1 were used instead of the primary antibody. After blocking endogenous peroxidase activity with $0.3 \% \mathrm{H}_{2} \mathrm{O}_{2}$ in methanol, sections were processed with Histofine Simple Stain MAX-PO(M) (Nichirei) for Runx2 and nestin, and with Histofine Simple Stain MAX-PO(R) (Nichirei) for osteocalcin, osteopontin, and DMP1. Anti-Runx 2 antibody binding sites were then visualized as a black reaction product by applying $0.05 \%$ 3,3'-diaminobenzidine (DAB), $0.01 \%$ nickel chloride, and $0.01 \% \mathrm{H}_{2} \mathrm{O}_{2}$ in a phosphate buffer for $8 \mathrm{~min}$, while the other antibody binding sites were colored brown by incubation with DAB solution (the solution used above without nickel chloride). Some sections stained with antiRunx2 were double-labeled with antibodies for nestin, osteocalcin, osteopontin, or DMP1. Finally, sections were counterstained with methyl green.

\section{Results}

\section{Expression pattern of Runx2 in wild-type and $\mathrm{Tg}$ (Col1a1-Runx2) mice}

Runx 2 protein was detected in the nuclei of preodontoblasts, immature odontoblasts, mesenchymal cells in the dental sac, and osteoblasts in wild-type mice at 3 days of age (Fig. 1a, b). Runx 2 protein was transiently detected in ameloblasts in the coronal regions of wildtype mice at one week of age as previously reported (Fig. 1c, d) (D'Souza et al., 1999; Jiang et al., 1999; Camilleri and McDonald 2006). The expression pattern of the 


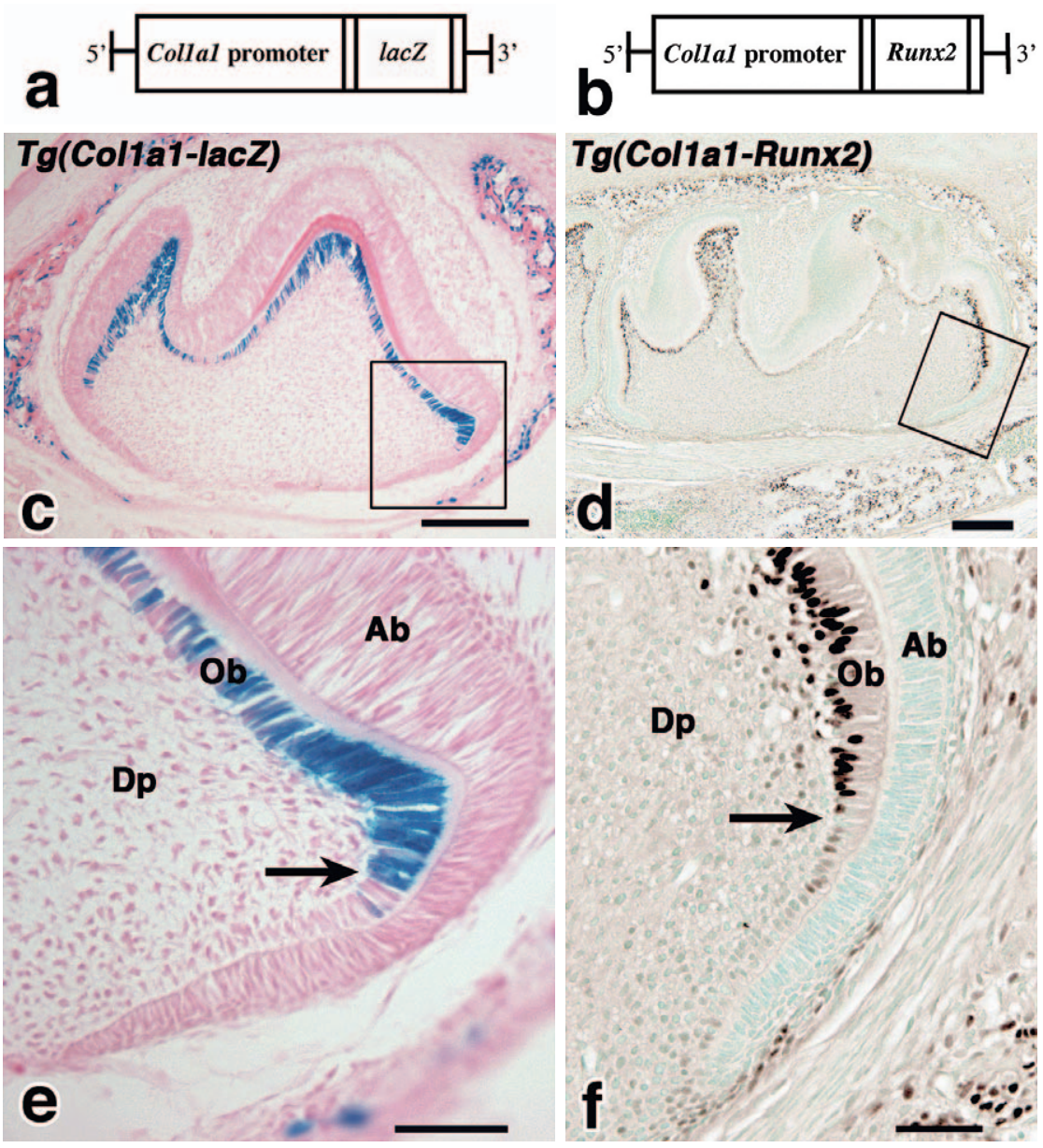

Fig. 2. Generation of transgenic mice. $\mathbf{a}$ and $\mathbf{b}$ : Diagrams of DNA constructs used to generate $\mathrm{Tg}$ (Collal-lacZ) mice (a) and $\operatorname{Tg}($ Colla1-Runx2) mice (b). c-f: Histochemical analysis of the odontoblastspecific expression of the transgene, using $\beta$-galactosidase staining (c, e) and Runx 2 immunostaining $(\mathbf{d}, \mathbf{f})$, in the lower first molars of 3-day-old Tg(Collal-lacZ) (c, e) and $\operatorname{Tg}($ Colla1-Runx2) $(\mathbf{d}, \mathbf{f})$ mice. Boxed regions in $\mathbf{c}$ and $\mathbf{d}$ are magnified in $\mathbf{e}$ and $\mathbf{f}$, respectively. $\beta$-galactosidase and Runx 2 are localized specifically in the cytoplasm and nuclei of odontoblasts, respectively, and were found with the onset of dentinogenesis (e, f, arrows). Ab: ameloblasts, Dp: dental papilla, Ob: odontoblasts. Bars $=200 \mu \mathrm{m}(\mathrm{c}, \mathrm{d}), 50 \mu \mathrm{m}$ $(e, f)$

transgene in the mandible was examined by $\beta$ galactosidase activity using lacZ transgenic mice under the control of the $2.3 \mathrm{~kb}$ Collal promoter ( $\mathrm{Tg}$ (CollallacZ) mice) at 3 days of age (Fig. 2a, c, e). In the tooth germs of the first molars of $\mathrm{Tg}$ (Colla1-lacZ) mice, $\beta$-galactosidase activity was localized specifically in odontoblasts and osteoblasts. The $\beta$-galactosidase activity was not detetcted in preodontoblasts, but it appeared with the onset of dentinogenesis (Fig. 2c, e). As the $\beta$ galactosidase activity was not detected in periodontal ligament cells or cementoblasts, which produce type I collagen, the $2.3 \mathrm{~kb}$ Collal promoter region does not contain the binding sites for the transcription factors that are required for the expression in these cells. In $\operatorname{Tg}$ (Collal-Runx2) mice, Runx2 was strongly detected in the nuclei of odontoblasts and osteoblasts, as seen in Tg(Collal-lacZ) mice (Fig. 2b, c-f).
The teeth of $\operatorname{Tg}($ Collal-Runx2) mice were fragile, with erupted teeth frequently showing breakage or dental pulp exposure (Fig. 3). The mineral density of incisors in $T g$ (Collal-Runx2) mice at six weeks of age was markedly decreased compared with that of wild-type mice in analysis using peripheral quantitative computed tomography (pQCT) (data not shown).

\section{Disturbance of odontoblast differentiation in Tg(Col1a1-Runx2) mice}

Morphologies of preodontoblasts and immature odontoblasts were similar between the tooth germs of wild-type and $\operatorname{Tg}$ (Colla1-Runx2) newborn mice (data not shown). At 3 days of age, odontoblasts in the first molar of wildtype mice were columnar. Odontoblasts in $\mathrm{Tg}$ (CollalRunx2) mice were also columnar at the cervical loop 
where odontoblasts were immature, but they lost this shape in cusp regions where dentinogenesis advanced and dentin was deposited around odontoblasts (Fig. 4af). At one week of age, dentin was apparently thin in $\operatorname{Tg}($ Colla1-Runx2) mice compared with that in wildtype mice, and odontoblasts in $\mathrm{Tg}(\mathrm{Colla1}-\mathrm{Runx} 2)$ mice lost their columnar shape in the whole area and were surrounded by dentin, exhibiting a bone structure (Fig. $4 \mathrm{~g}-1)$. No formation of predentin and dentinal tubules was observed in $T g$ (Collal-Runx2) mice (Fig. 4k, 1).

Although there was little difference in the contour of the first molar between wild-type and $T g$ (Collal-Runx2) mice at 4 weeks of age (Fig. 5a, d), dentin in $\mathrm{Tg}$ (CollalRunx2) mice was thinner and did not possess structures peculiar to normal dentin, such as predentin and dentinal tubules (Fig. 5, 6). The dentin possessed lacunae that contained odontoblasts, which were similar to alveolar bone in structure (Fig. 5f). Silver impregnation staining showed that the dentin had bone canaliculi-like structures around their lacunae in $\operatorname{Tg}($ Collal-Runx 2$)$ mice, but that the alveolar bone had fewer canaliculi than in wild-type mice (Fig. 6). In coronal regions, the bone structures were frequently observed in molars of $T g($ Collal-Runx2) mice (Fig. 5e). Odontoblasts were polarized and columnar in wild-type mice, while odontoblasts in $\mathrm{Tg}(\mathrm{Collal}$ Runx2) mice were cuboid or flat (Fig. 5c, f). These findings were clearly visualized by electron microscopy at one week of age (Fig. 7). In Tg(Collal-Runx2) mice, structural changes in odontoblasts became apparent where enamel deposition began, and ectopical secretion of collagen fibers by depolarized odontoblasts was seen among odontoblasts (Fig. 7b). At coronal regions where dentinogenesis had advanced, some odontoblasts were embedded in dentin like osteocytes and others were located on the surface of dentin like osteoblasts, with both being flat or cuboid (Fig. 7d). Enamel deposition was partly disturbed in the apical region of $\operatorname{Tg}($ Collal-Runx2) mice (Fig. 41).

\section{Expression of dentin matrix proteins and nestin in Tg(Col1a1-Runx2) mice}

To investigate the characteristics of odontoblasts in $T g$ (Collal-Runx2) mice, we examined the expressions of two dentin matrix protein genes, Collal and DSPP, by in situ hybridization, the dentin matrix proteins, osteocalcin, osteopontin, and DMP1, and an intermediate filament, nestin, by immunohistochemistry. Collal expression was similarly detected in odontoblasts of wild-type and Tg(Colla1-Runx2) mice at 3 days of age (Fig. 8a, b, e, f); however, Collal expression in odontoblasts was apparently reduced in $\mathrm{Tg}($ Collal-Runx2) mice compared

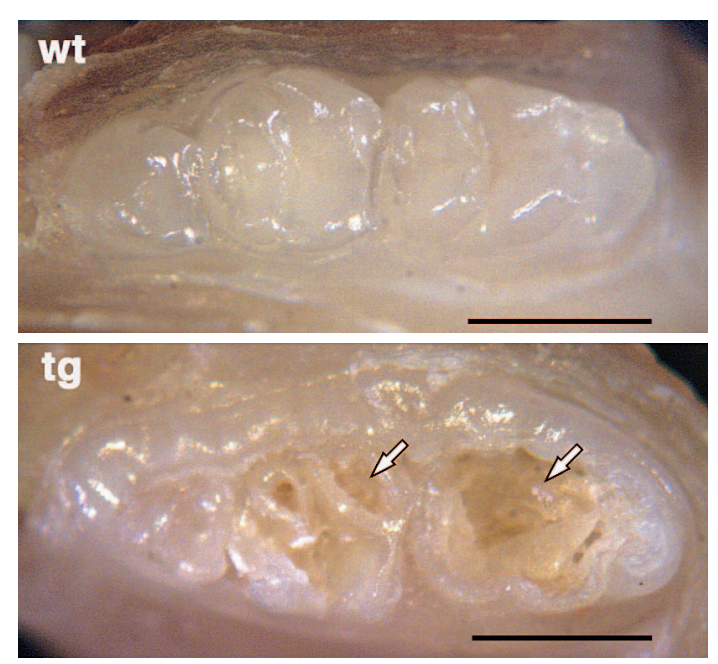

Fig. 3. Appearance of molars in $T g($ Colla1-Runx2) mice. Appearances of the lower left molars of 4month-old wild-type (wt) and $\operatorname{Tg}($ Colla1-Runx2) (tg) mice are shown. The teeth of $\operatorname{Tg}($ Colla1-Runx 2$)$ mice are fragile and breakage or dental pulp exposure is seen after eruption (arrows). Bars $=1 \mathrm{~mm}$

with wild-type mice at one week of age (Fig. 8i, j, m, n). $D S P P$ expression was strongly detected in odontoblasts of wild-type mice at 3 days and one week of age, whereas $D S P P$ expression in odontoblasts was severely reduced at 3 days of age compared with that in wild-type mice, and was barely detectable at one-week-old $T g$ (Colla1-Runx2) mice (Fig. 8c, d, g, h, k, 1, o, p). On the other hand, DSPP expression in ameloblasts was similarly observed in wildtype and $\operatorname{Tg}$ (Collal-Runx2) mice (Fig. 8g, h, o, p).

We examined the expression of nestin, a marker of odontoblasts, and Runx 2 by double labeling using antinestin and anti-Runx2 antibodies. In the tooth germs of wild-type mice, preodontoblasts expressed Runx 2 but not nestin, and odontoblasts expressed nestin but almost no Runx 2 at 3 days and one week of age (Fig. 9a, c). At these times, nestin was also expressed in cells under the odontoblast layer (Fig. 9a, c). At 4 weeks, nestin was restrictively localized in the cytoplasm of odontoblasts and the odontoblast processes (Fig. 10a, b). In $\mathrm{Tg}$ (CollalRunx2) mice, nestin expression in odontoblasts was reduced at 3 days and further reduced at one week of age, while nestin expression in cells under the odontoblast layer was similar to that in wild-type mice (Fig. 9). At 4 weeks of age, nestin was barely detectable in the odontoblasts in the molars of $T g($ Colla1-Runx 2$)$ mice (Fig. 10c, d).

We examined the expressions of osteocalcin and Runx 2 


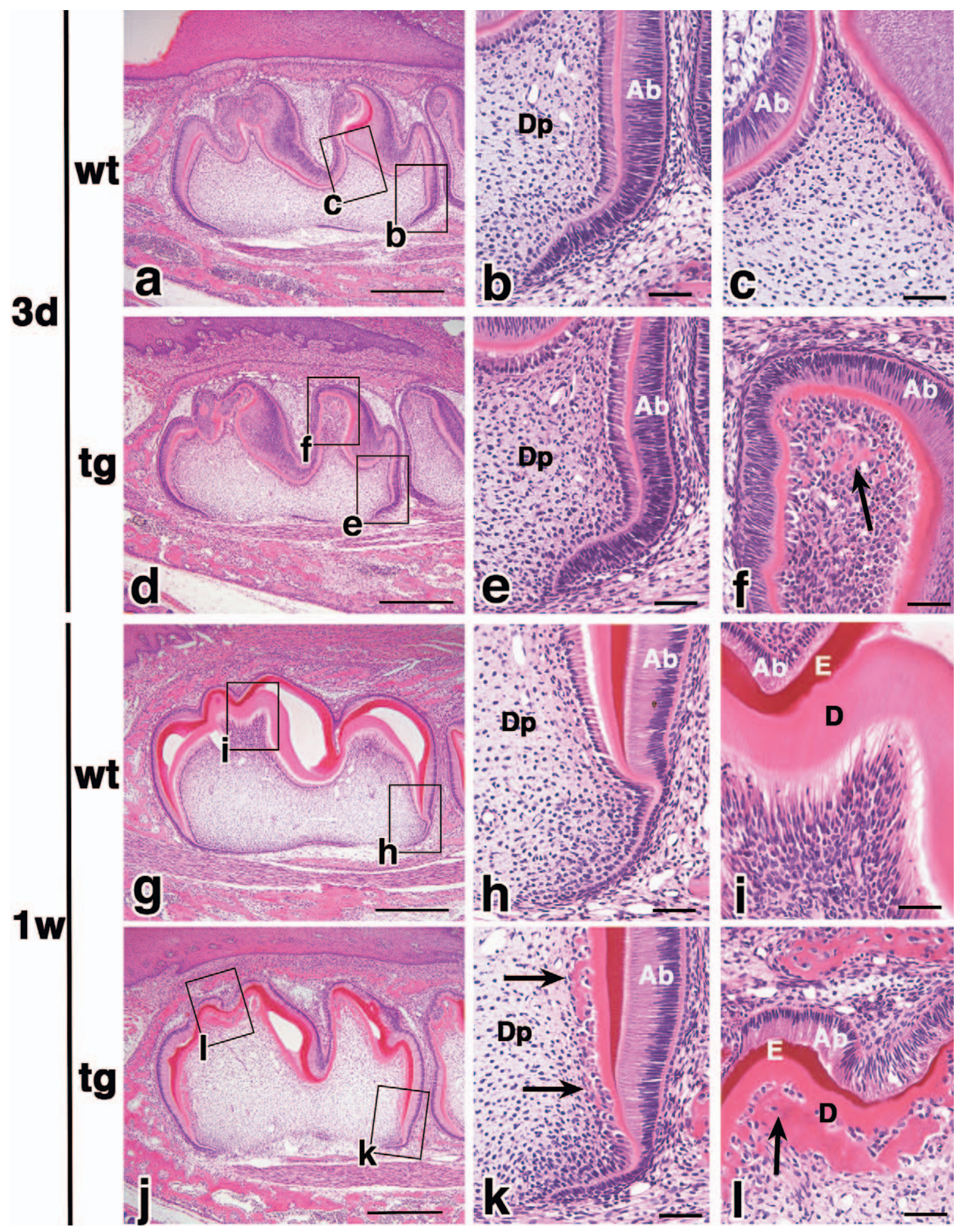

Fig. 4. Legend on the opposite page. 

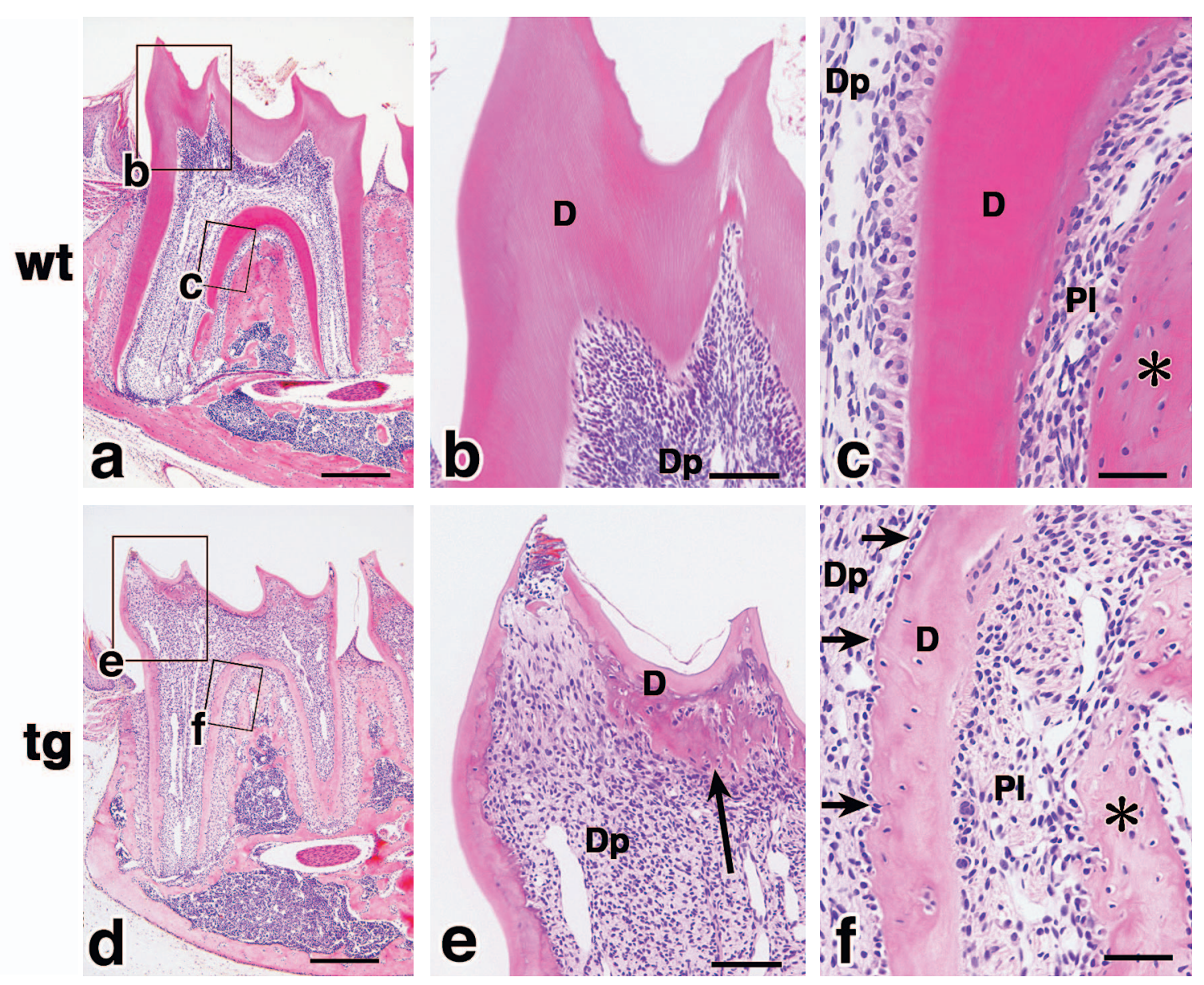

Fig. 5. Light micrographs of the lower first molars at 4 weeks of age. Sections of lower first molars of 4week-old wild-type (wt) (a-c) and $T g($ Colla1-Runx2) (tg) (d-f) mice were stained with haematoxylin and eosin. Sections of $\mathbf{b}, \mathbf{c}, \mathbf{e}$ and $\mathbf{f}$ are magnifications of boxed areas in $\mathbf{a}$ and $\mathbf{d}$. The dentin in $\operatorname{Tg}$ (CollalRunx2) mice is thinner than in wild-type mice and shows a bone structure (f), which resembles alveolar bone (c, $\mathbf{f}$, asterisks). The bone structure is also seen in the coronal pulp region (e, long arrow). Odontoblasts in $\mathrm{Tg}($ Colla1-Runx2) mice lose their columnar structure (f, short arrows). D: dentin, Dp: dental pulp, Pl: periodontal ligament. Bars $=400 \mu \mathrm{m}(\mathrm{a}, \mathrm{d}), 100 \mu \mathrm{m}(\mathrm{b}, \mathrm{e}), 50 \mu \mathrm{m}(\mathrm{c}, \mathrm{f})$

Fig. 4. Light micrographs of tooth germs at 3 days and one week of age. Sections of tooth germs of first molars in wild-type (wt) (a, b, c, $\mathbf{g}, \mathbf{h}, \mathbf{i})$ and $\operatorname{Tg}($ Collal-Runx2) (tg) (d, e, f, j, k, l) mice at 3 days (a-f) and one week (g-l) were stained with haematoxylin and eosin. Sections of $\mathbf{b}, \mathbf{e}, \mathbf{h}$, and $\mathbf{k}$ are magnifications of the cervical loop regions indicated by boxes in $\mathbf{a}, \mathbf{d}, \mathbf{g}$, and $\mathbf{j}$, respectively. Sections of $\mathbf{c}, \mathbf{f}, \mathbf{i}$ and $\mathbf{l}$ are magnifications of the coronal regions indicated by boxes in $\mathbf{a}, \mathbf{d}, \mathbf{g}$ and $\mathbf{j}$, respectively. There is no difference in the contour of tooth germs between wildtype and $\operatorname{Tg}($ Collal-Runx2) mice, but the thickness of the dentin is extremely thin in the latter. In the early stage of dentinogenesis, odontoblasts of transgenic mice are morphologically similar to those of wild-type mice (b, e); thereafter, they lose their polarized, columnar shape as dentinogenesis advances (compare $\mathbf{f}, \mathbf{k}$ and $\mathbf{l}$ with $\mathbf{c}, \mathbf{h}$ and $\mathbf{i}$, respectively). Odontoblasts in $\operatorname{Tg}($ Colla1-Runx2) mice are surrounded by dentin (f, k, l, arrows). Ab: ameloblasts, D: dentin, Dp: dental papilla, E: enamel. Bars $=400 \mu \mathrm{m}(\mathrm{a}, \mathrm{d}, \mathrm{g}, \mathrm{j}), 50 \mu \mathrm{m}(\mathrm{b}, \mathrm{c}, \mathrm{e}, \mathrm{f}, \mathrm{h}, \mathrm{i}, \mathrm{k}, \mathrm{l})$ 

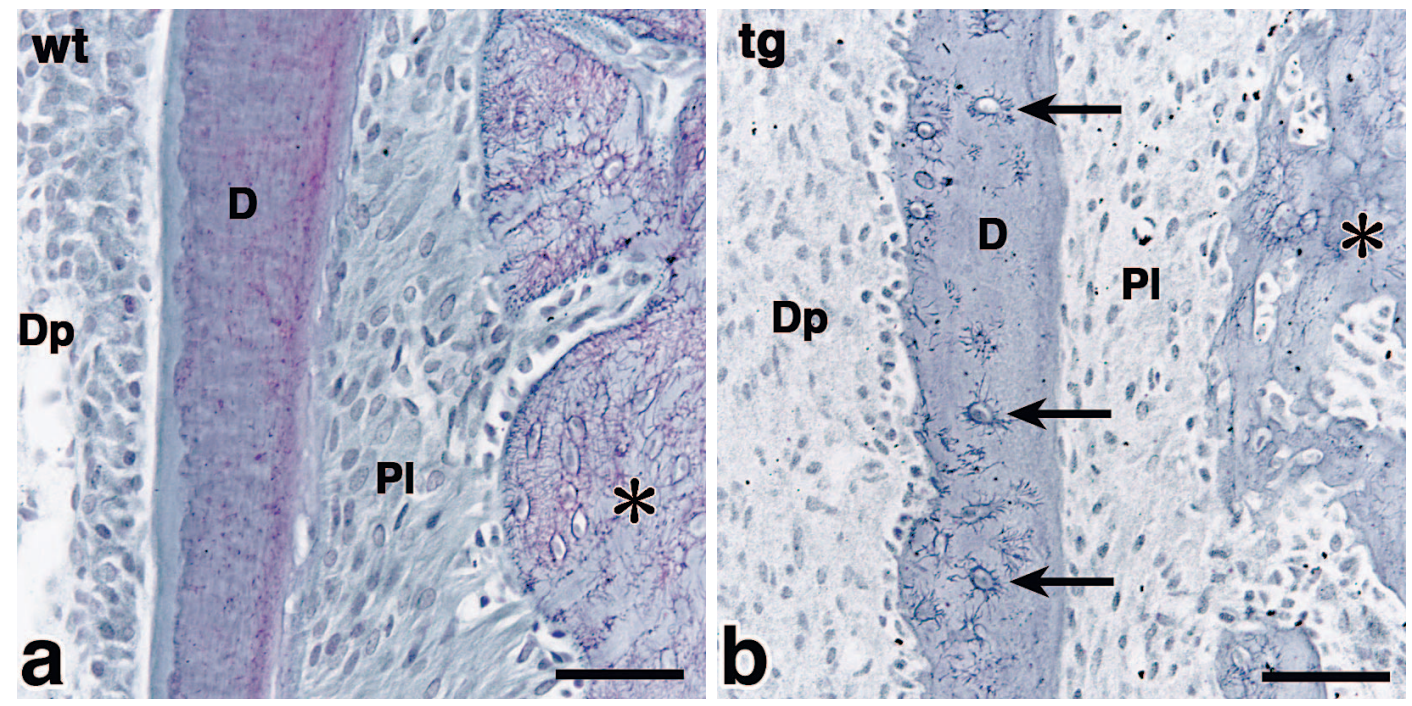

Fig. 6. Silver impregnation staining. Sections of the lower first molars of 4-week-old wild-type (wt) (a) and $T g($ Colla1-Runx2) (tg) (b) mice were stained with a silver impregnation staining method and the root areas are shown. Bone lacuna structures with canaliculi are seen in the dentin of $\operatorname{Tg}$ (Colla1-Runx2) mice (b, arrows). Asterisks indicate alveolar bone. D: dentin, Dp: dental pulp, Pl: periodontal ligament. Bars $=50 \mu \mathrm{m}$

by double labeling using anti-osteocalcin and anti-Runx2 antibodies. In wild-type mice, osteocalcin was expressed weakly in odontoblasts at 3 days but strongly at one week of age, while odontoblasts - which expressed osteocalcin - did not express Runx2, but a significant number of osteoblasts expressed both osteocalcin and Runx2 (Fig. 11a-c, g-i). In 3-day-old Tg(Collal-Runx2) mice, osteocalcin expression was increased in odontoblasts as compared with wild-type mice, and Runx 2 was strongly detected in odontoblasts (Fig. 11a, b, d, e). At one week of age, however, osteocalcin expression was decreased in most odontoblasts, except for those at the cervical loop in which odontoblasts maintained their columnar shape, although Runx2 was strongly detected in most odontoblasts (Fig. 11j, k). Osteocalcin expression in osteoblasts was lower in $T g($ Colla1-Runx2) mice than in wild-type mice, as previously described (Liu et al., 2001; Kanatani et al., 2006) (Fig. 11c, f, i, l).

Osteopontin protein was detected in the alveolar bone and cementum but not in dentin in wild-type mice, while it was strongly detected in the alveolar bone, cementum, and dentin in $T g$ (Collal-Runx2) mice (Fig. 12a b, e, f, i, j, $\mathrm{m}, \mathrm{n})$. DMP1 protein was detected strongly in the alveolar bone, especially around canaliculi, and in the cementum, but weakly in dentin in wild-type mice, while the DMP1 protein was detected weakly in the alveolar bone but strongly in the dentin and cementum in $\mathrm{Tg}(\mathrm{Collal}$ Runx2) mice (Fig. 12c, d, g, h, k, 1, o, p). The deposition of osteopontin and DMP1 was prominent in the bone structures in the coronal regions of $\operatorname{Tg}($ Colla1-Runx2) mice (Fig. 12f, h, n, p).

\section{Discussion}

Odontoblasts in Tg(Colla1-Runx2) mice lost their polarized, columnar features, and the dentin did not show its typical structures - such as dentinal tubules or predentin - but did show the appearance of bone, in which bone lacuna-like structures containing cellular inclusion were present. The gene expression of DSPP, which is known to be a tooth-specific protein (D'Souza et al., 1997; Begue-Kirn et al., 1998), was down-regulated in odontoblasts of $\mathrm{Tg}(\mathrm{Colla1}-\mathrm{Runx} 2)$ mice. Further, an immunohistochemical analysis of nestin, which is also an odontoblast marker protein and is not expressed in osteoblasts (Terling et al., 1995; About et al., 2000; Struys et al., 2005), showed distinct down-regulation in odontoblasts in $\mathrm{Tg}(\mathrm{Colla1}-\mathrm{Run} \times 2)$ mice. In contrst to the reduction of these odontoblast-specific proteins, osteopontin and DMP1, which are noncollagenous 

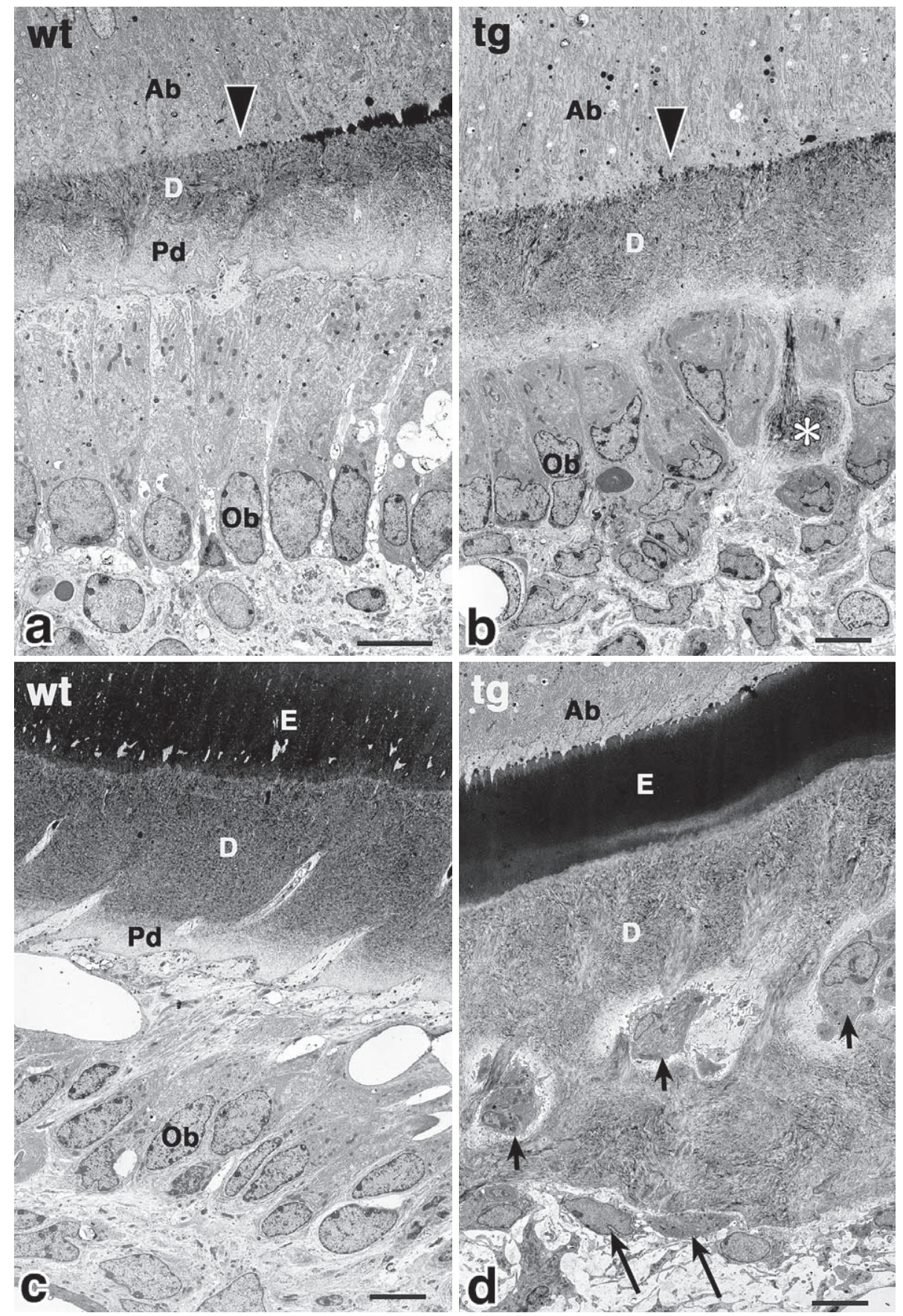

Fig. 7. Electron micrographs. Section of tooth germs of lower first molars in wild-type (wt) (a, c) and $\mathrm{Tg}(\mathrm{Colla1}$ Runx2) (tg) (b, d) mice at 1 week of age were examined by transmission electron microscopy, and odontoblasts/ dentin/enamel layer interfaces at early $(\mathbf{a}, \mathbf{b})$ and late $(\mathbf{c}, \mathbf{d})$ stages of dentinogenesis are shown. Odontoblasts in wild-type mice exhibit a polarized, columnar shape (a, c), whereas those in $\operatorname{Tg}($ Colla1-Runx2) mice begin to lose their configuration and dentin is deposited in the odontoblast layer (b, asterisk) when enamel deposition starts (a, b, arrowheads). In the late stage of dentinogenesis, odontoblasts are enclosed by dentin (d, short arrows) or located on the surface of dentin (d, long arrows), being cuboid or flat. Ab: ameloblasts, D: dentin, E: enamel, Ob: odontoblasts, Pd: predentin. Bars $=5 \mu \mathrm{m}$ 


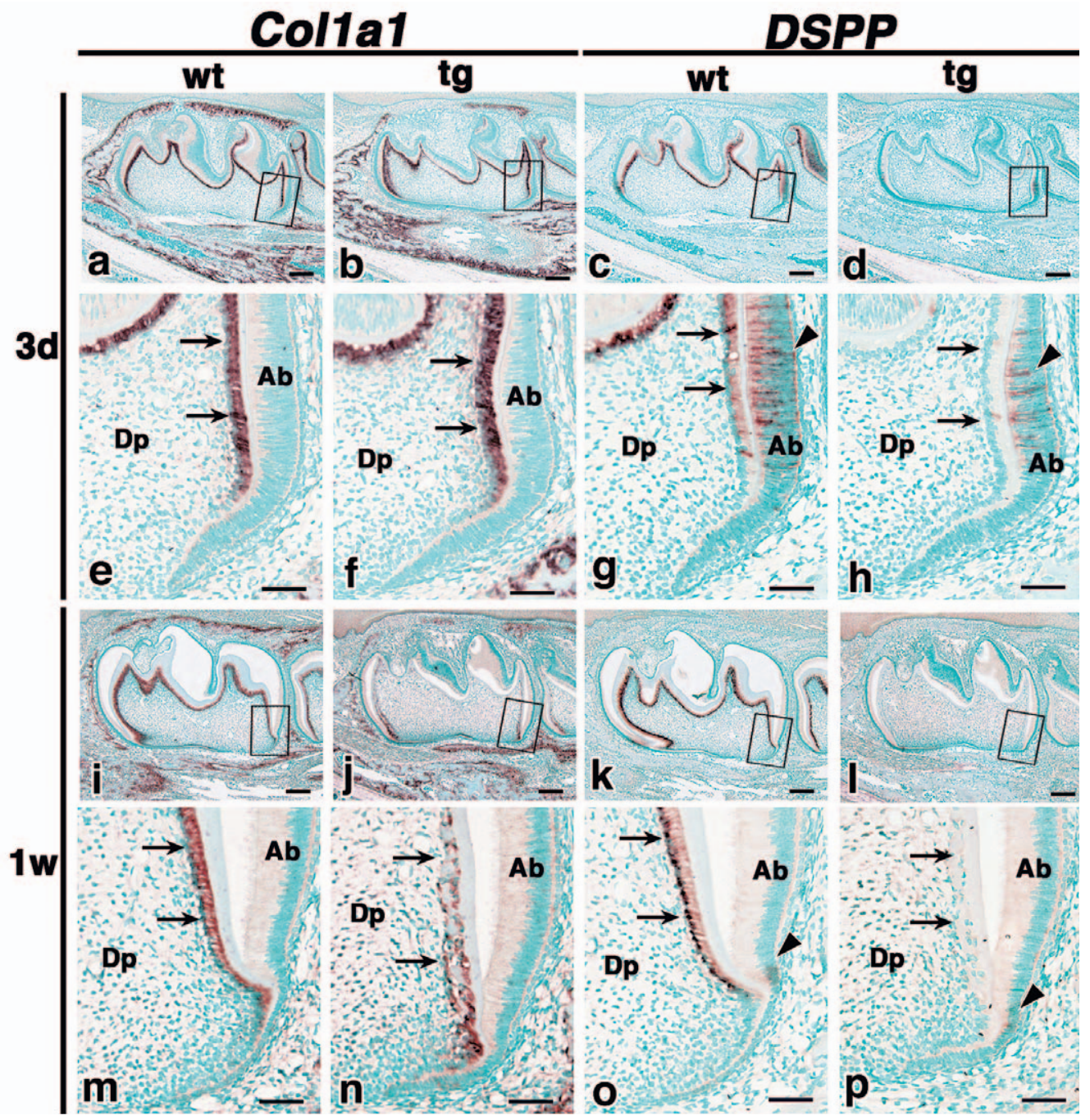

Fig. 8. In situ hybridization using Collal and DSPP probes. Expression of Collal (a, b, e, f, i, j, $\mathbf{m}, \mathbf{n})$ and $\operatorname{DSPP}(\mathbf{c}, \mathbf{d}, \mathbf{g}, \mathbf{h}, \mathbf{k}, \mathbf{l}, \mathbf{o}, \mathbf{p})$ mRNAs in the tooth germs of first molars in wild-type (wt) (a, c, e, $\mathbf{g}, \mathbf{i}, \mathbf{k}, \mathbf{m}, \mathbf{o})$ and $\operatorname{Tg}(\operatorname{Collal}-\operatorname{Run} x 2)(\operatorname{tg})(\mathbf{b}, \mathbf{d}, \mathbf{f}, \mathbf{h}, \mathbf{j}, \mathbf{l}, \mathbf{n}, \mathbf{p})$ mice at 3 days $(\mathbf{a}-\mathbf{h})$ and one week (i-p) of age were examined by in situ hybridization. Boxed regions in $\mathbf{a}, \mathbf{b}, \mathbf{c}, \mathbf{d}, \mathbf{i}, \mathbf{j}, \mathbf{k}$ and $\mathbf{l}$ are magnified in $\mathbf{e}, \mathbf{f}, \mathbf{g}, \mathbf{h}, \mathbf{m}, \mathbf{n}, \mathbf{o}$, and $\mathbf{p}$, respectively. Collal signals are strongly observed in odontoblasts of both wild-type and $\operatorname{Tg}($ Colla1-Runx2) mice at 3 days of age (a, b, e, f, arrows), but are apparently reduced in $\operatorname{Tg}($ Colla1-Runx2) mice at one week (i, j, $\mathbf{m}, \mathbf{n}$, arrows). DSPP signals are detected in odontobasts in wild-type mice at 3 days and one week $(\mathbf{c}, \mathbf{g}, \mathbf{k}, \mathbf{o}$, arrows), but are severely reduced at 3 days (d, $\mathbf{h}$, arrows) and barely detectable at one week (l, $\mathbf{p}$, arrows) in $T g($ Colla1-Runx2) mice. DSPP signals are similarly observed in amoloblasts of wild-type and $\operatorname{Tg}($ Colla1-Runx2) mice (g, h, o, p, arrowheads). Ab: ameloblasts, Dp: dental papilla. Bars = $200 \mu \mathrm{m}(\mathrm{a}-\mathrm{d}, \mathrm{i}-1), 50 \mu \mathrm{m}(\mathrm{e}-\mathrm{h}, \mathrm{m}-\mathrm{p})$. 
Fig. 9. Immunohistochemical analysis of nestin at 3 days and one week of age. Expressions of nestin and Runx 2 proteins in the tooth germs of first molars in wildtype (wt) (a, c) and $\operatorname{Tg}($ Collal-Runx2) (tg) $(\mathbf{b}, \mathbf{d})$ mice at 3 days $(\mathbf{a}, \mathbf{b})$ and one week (c, d) were examined by imunohistochemistry. Sections were double-labeled with anti-nestin and anti-Runx 2 antibodies. The localization of nestin is stained brown and that of Runx2 is stained black. Nestin immunostaining is observed in odontoblasts $(\mathrm{Ob})$ and cells under the odontoblast layers (asteriks) in wild-type mice $(\mathbf{a}, \mathbf{c})$, while staining in odontoblasts $(\mathrm{Ob})$ but not that in cells under the odontoblast layers (asteriks) is markedly reduced in $T g($ Colla1-Runx2) mice (b, d). Arrows indicate preodontoblasts, which express endogenous Runx2. Ab: ameloblasts, Dp: dental papilla. Bars $=50 \mu \mathrm{m}$

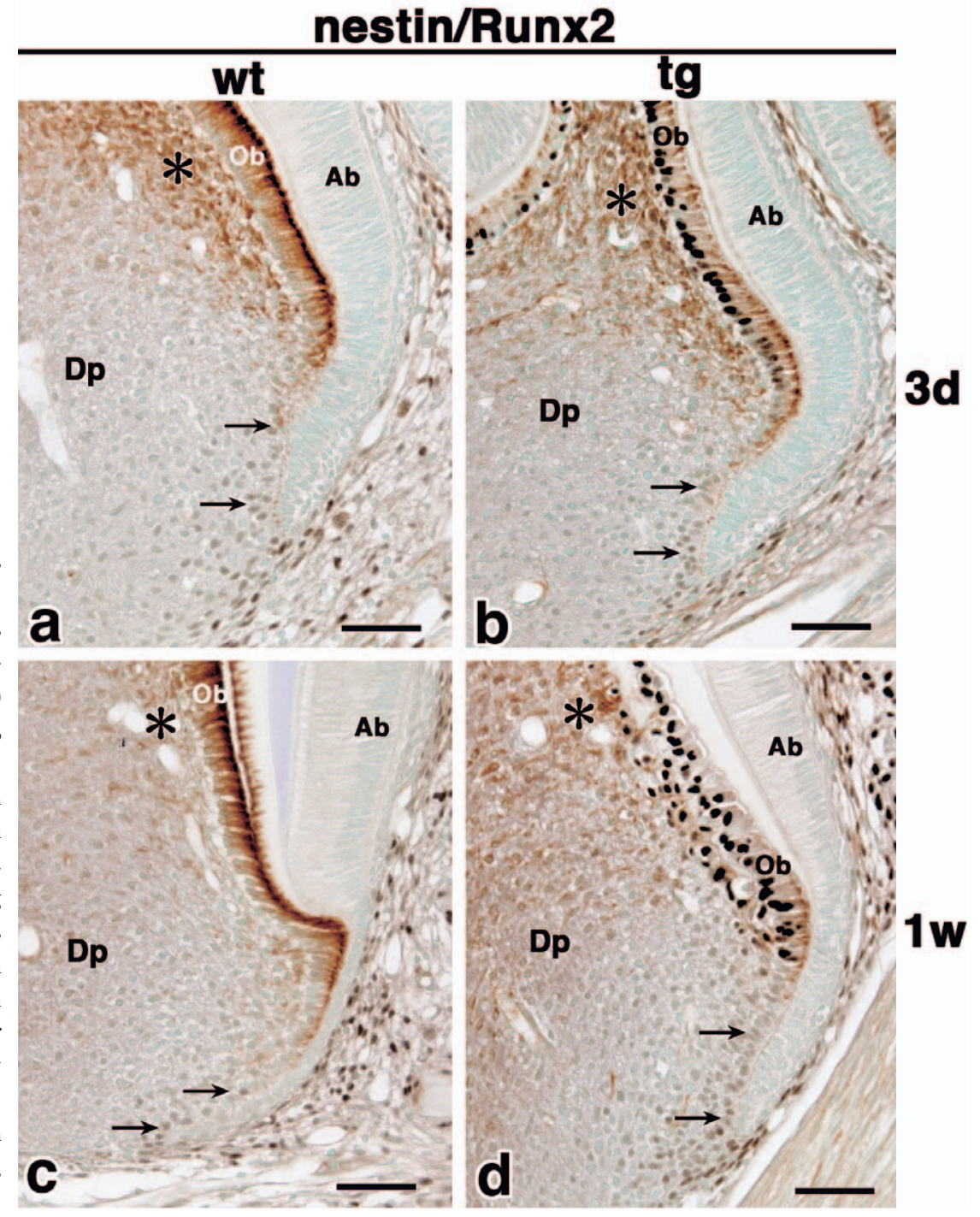

proteins present in both bone and teeth but with higher expression levels in the former (D'Souza et al., 1997; Toyosawa et al., 2001; Aguiar and Arana-Chavez, 2007), were increased in the dentin of $T g($ Collal-Runx2) mice. These findings indicate that odontoblasts in $\mathrm{Tg}$ (CollalRunx2) mice lost the phenotypes of odontoblasts and acquired those of osteoblasts.

The mRNA of type I collagen, a major organic component of bone and dentin, was similarly expressed in immature odontoblasts of both wild-type and $\operatorname{Tg}($ Collal-Runx2) mice; however, it decreased after the transdifferentiation from odontoblasts to osteoblasts in $\operatorname{Tg}($ Colla1-Runx2) mice. The expression of osteocalcin, another protein found in bone and dentin, was upregulated in immature odontoblasts, but it was also downregulated after the transdifferentiation in $T g($ Colla1-Runx2) mice. Similarly, the expression of type I collagen and osteocalcin in individual osteoblasts was reduced in $\operatorname{Tg}($ Colla1-Runx2) mice because of the inhibition of osteoblast maturation (Liu et al., 2001; Kanatani et al., 2006). After the transdifferentiation from odontoblasts to osteoblasts, therefore, maturational inhibition also seems to have occurred in the osteoblasts. In addition, Runx2 triggers osteocalcin expression in osteoprogenitor cells, although Runx 2 is not essential for the steadystate expression of osteocalcin in mature osteoblasts 


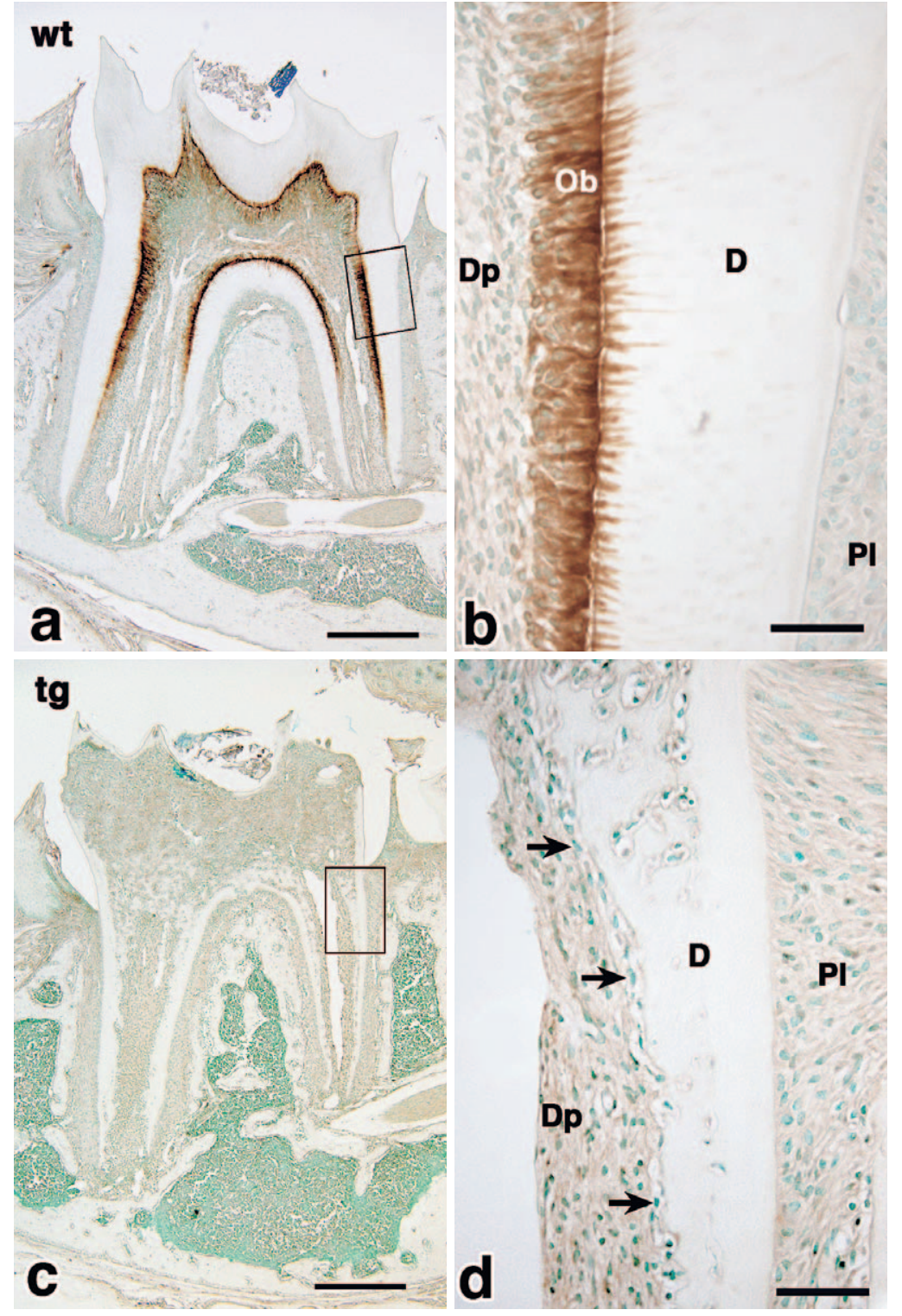

Fig. 10. Immunohistochemical analysis of nestin at 4 weeks of age. Expressions of nestin proteins in lower first molars of 4-week-old wild-type (a, b) and $\operatorname{Tg}($ Colla1-Runx2) (c, d) mice were examined by immunohistochemistry. Boxed regions in $\mathbf{a}$ and $\mathbf{c}$ are magnified in $\mathbf{b}$ and $\mathbf{d}$, respectively. Nestin is exclusively localized in the cytoplasm and process of odontoblasts in wildtype mice (a, b), while it is absent in $\mathrm{Tg}$ (CollalRunx2) mice (c, d, arrows). D: dentin, Dp: dental pulp, Ob: odontoblasts, $\mathrm{Pl}$ : periodontal ligament. Bars $=400 \mu \mathrm{m}(\mathrm{a}, \mathrm{c}), 50 \mu \mathrm{m}(\mathrm{b}, \mathrm{d})$.
(Maruyama et al., 2007). At an early stage of the transdifferentiation from odontoblasts to osteoblasts, therefore, osteocalcin may have been upregulated transiently. The transdifferentiation also partly affected amelogenesis, indicating that a failure of terminal differentiation of odontoblasts could affect amelogenesis. This implies that the interaction between mesenchymal cells and epithelial cells still plays an important role at their terminal differentiation stages.

DSPP is a vital non-collagenous protein for tooth development. The teeth of Dspp-deficient mice show defective and reduced dentin mineralization and pulp exposure similar to those of human dentinogenesis imperfecta III (Sreenath et al., 2003). In newly differentiated and functional odontoblasts, it has been shown that Runx 2 expression is down-regulated, whereas DSPP is upregulated (Gaikwad et al., 2001; Chen et al., 2005). Runx2 overexpression in odontoblast cell lines, such as MDPC23 cells and MO6-G3 cells, resulted in the selective down-regulation of DSPP (Gaikwad et al., 2001; Chen et al., 2005). Our findings, combined with previous findings, suggest that the down-regulation of Runx2 in odontoblasts 


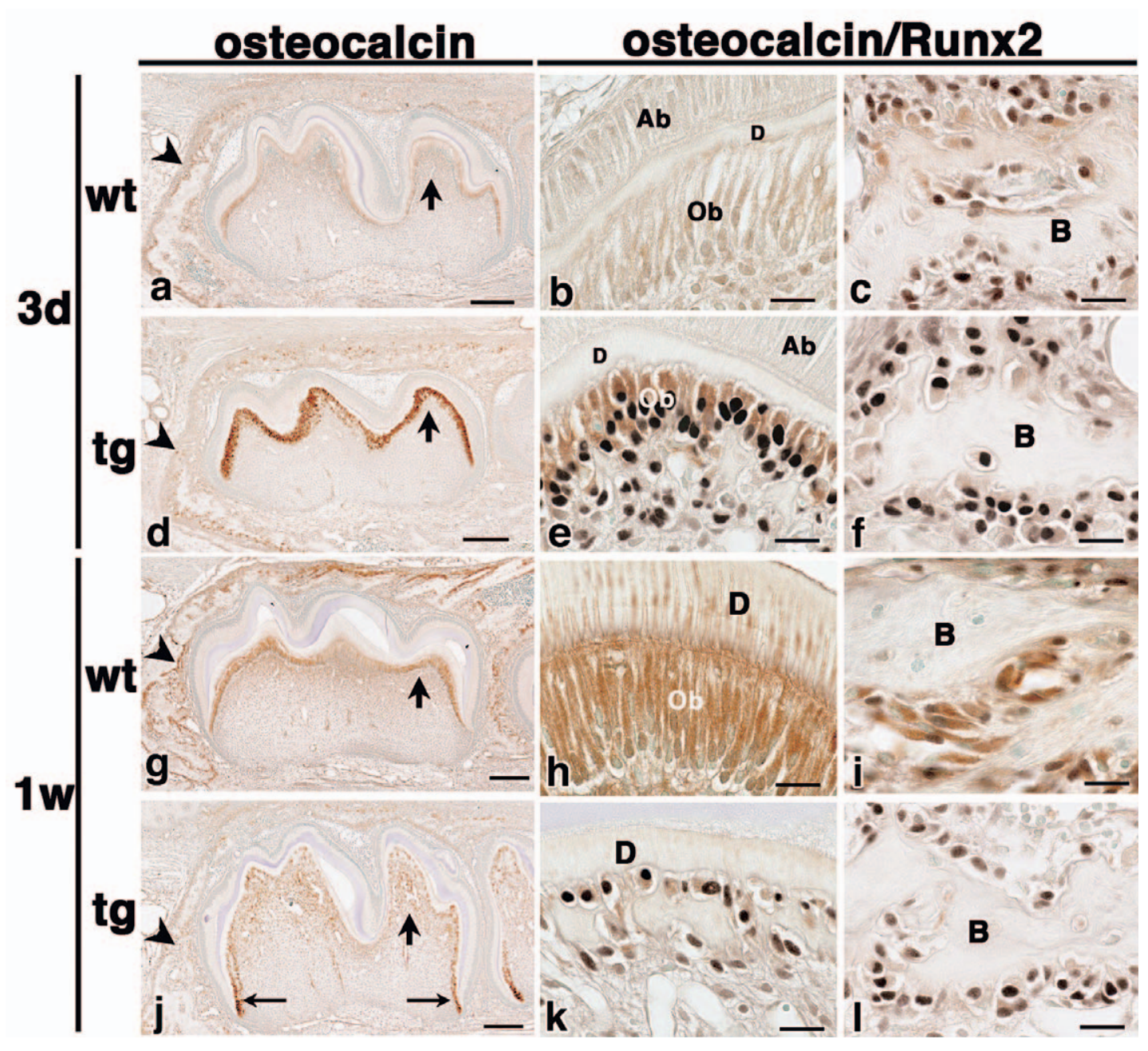

Fig. 11. Immunohistochemical analysis of osteocalcin. Expressions of osteocalcin and Runx2 proteins in the tooth germs of first molars in wild-type (wt) (a-c, $\mathbf{g}-\mathbf{i})$ and $\mathrm{Tg}$ (CollalRunx2) (tg) $(\mathbf{d}-\mathbf{f}, \mathbf{j}-\mathbf{l})$ mice at 3 days $(\mathbf{a}-\mathbf{f})$ and one week $(\mathbf{g}-\mathbf{l})$ of age were examined by immunohistochemistry. Sections were single-labeled with an osteocalcin antibody $(\mathbf{a}, \mathbf{d}, \mathbf{g}, \mathbf{j})$ or double-labeled with osteocalcin and Runx2 antibodies (b, $, \mathbf{e}, \mathbf{f}, \mathbf{h}, \mathbf{i}, \mathbf{k}, \mathbf{l}$ ). The localization of osteocalcin is stained brown and that of Runx 2 is stained black. $\mathbf{b}, \mathbf{e}, \mathbf{h}$ and $\mathbf{k}$ show cusp regions in sections adjacent to $\mathbf{a}, \mathbf{d}, \mathbf{g}$ and $\mathbf{j}$, respectively (short arrows). $\mathbf{c}, \mathbf{f}, \mathbf{i}$ and $\mathbf{l}$ show alveolar bone in sections adjacent to $\mathbf{a}, \mathbf{d}, \mathbf{g}$ and $\mathbf{j}$, respectively (arrowheads). Differentiated odontoblasts in wildtype mice do not express Runx 2 but express osteocalcin weakly at 3 days and strongly at one week of age (a, $\mathbf{b}, \mathbf{g}, \mathbf{h})$, while a significant number of osteoblasts express both osteocalcin and Runx 2 $(\mathbf{a}, \mathbf{c}, \mathbf{g}, \mathbf{i})$. Osteocalcin expression is enhanced in odontoblasts, which are positive for Runx2, in $\operatorname{Tg}$ (Colla1-Runx2) mice at 3 days of age (d, e), and is decreased in most odontoblasts, except young odontoblasts in the cervical loop region ( $\mathrm{j}$, long arrows) at one week $(\mathbf{j}, \mathbf{k})$. Osteocalcin expression in osteoblasts is reduced in $T g($ Collal-Runx2) mice (d, f, j, l). Ab: ameloblasts, B: bone, D: dentin, Ob: odontoblasts. Bars $=200 \mu \mathrm{m}(\mathrm{a}, \mathrm{d}, \mathrm{g}, \mathrm{j}), 20 \mu \mathrm{m}(\mathrm{b}, \mathrm{c}, \mathrm{e}, \mathrm{f}, \mathrm{h}, \mathrm{i}, \mathrm{k}, \mathrm{l})$ 


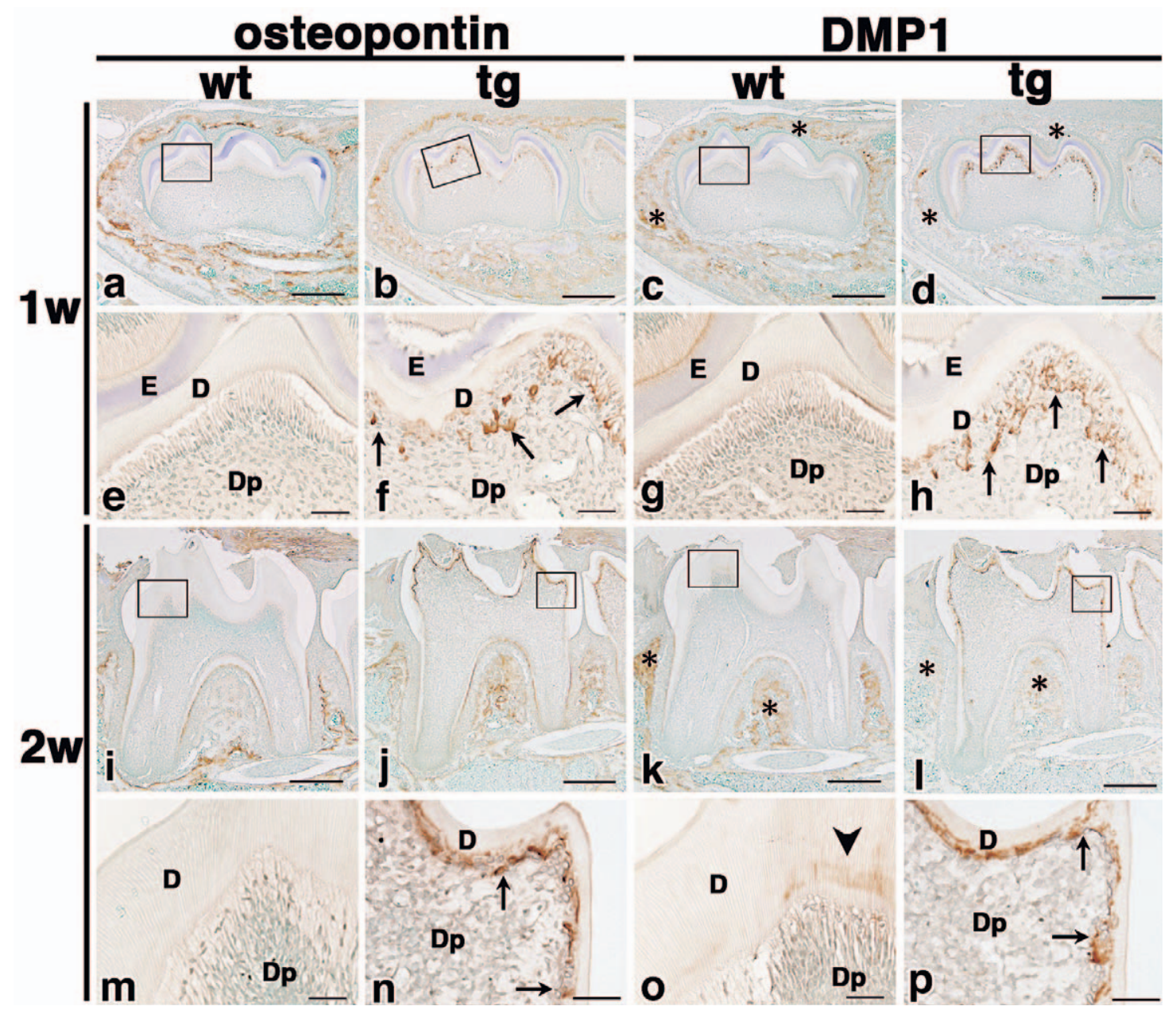

Fig. 12. Immunohistochemical analysis of ostepontin and DMP1. Expressions of osteopontin (a, b, e, f, i, $\mathbf{j}, \mathbf{m}, \mathbf{n})$ and DMP1 (c, $\mathbf{d}, \mathbf{g}, \mathbf{h}, \mathbf{k}, \mathbf{l}, \mathbf{o}, \mathbf{p})$ proteins in the tooth germs of first molars in wild-type (wt) (a, $\mathbf{c}$, $\mathbf{e}, \mathbf{g}, \mathbf{i}, \mathbf{k}, \mathbf{m}, \mathbf{o})$ and $T g($ Colla1-Runx2) $(\operatorname{tg})(\mathbf{b}, \mathbf{d}, \mathbf{f}, \mathbf{h}, \mathbf{j}, \mathbf{l}, \mathbf{n}, \mathbf{p})$ mice at one week $(\mathbf{a}-\mathbf{h})$ and 2 weeks $(\mathbf{i}-$ p) of age were examined by immunohistochemistry. Boxed regions in $\mathbf{a}-\mathbf{d}$ and $\mathbf{i}-\mathbf{l}$ are magnified in $\mathbf{e}-$ $\mathbf{h}$ and $\mathbf{m}-\mathbf{p}$, respectively. Both osteopontin and DMP1 are localized in the alveolar bone and cementum but not in the dentin in wild-type mice $(\mathbf{a}, \mathbf{c}, \mathbf{e}, \mathbf{g}, \mathbf{i}, \mathbf{m})$, although a weak immunoreactivity for DMP1 antibody is detected in the coronal dentin at 2 weeks of age ( $\mathbf{k}, \mathbf{o}$, arrowhead). Both are strongly detected in the bone structure in the coronal regions of $\operatorname{Tg}(\operatorname{Colla1-Runx} 2)$ mice $(\mathbf{b}, \mathbf{d}, \mathbf{f}, \mathbf{h}, \mathbf{j}, \mathbf{l}, \mathbf{n}, \mathbf{p}$, arrows), but immunoreactivity for DMP1 is decreased in the alveolar bone (compare $\mathbf{d}$ and $\mathbf{l}$ with $\mathbf{c}$ and $\mathbf{k}$, respectively, asteriks). E: enamel, D: dentin, Dp: dental papilla $(\mathbf{e}-\mathbf{h})$ or dental pulp $(\mathbf{m}-\mathbf{p})$. Bars $=400 \mu \mathrm{m}(\mathrm{a}-\mathrm{d}$ and $\mathrm{i}-1), 50 \mu \mathrm{m}(\mathrm{e}-\mathrm{h}$ and $\mathrm{m}-\mathrm{p})$

is required for DSPP expression and dentinogenesis.

Histological characteristics of the bone structure formed during dentinogenesis in $T g($ Collal-Runx2) mice were similar to those of reparative dentin, which has an atubular matrix with entrapped cells and exhibits a bone-like appearance. Although the mechanisms of the reparative dentine formation remain unclear, it has been shown that reparative dentin is formed by newly differentiated odontoblast-like cells that derive from pulp cells and share some structural characteristics with bone (Smith et al., 1995; Tziafas, 1995; Aran-Chavez and Massa, 2004; Aguiar and Aran-Chavez, 2007). 
Furthermore, it has been reported that osteopontin, DMP1, and osteocalcin are up-regulated in the formation of reparative dentin or in newly formed bone-like tissues in the pulp cavity after tooth replantation (Braut et al., 2003; Almushayt et al., 2006; Aguiar and Aran-Chavez, 2007; Mei et al., 2007; Zhao et al., 2007), and that the cells forming the bone-like tissues are Runx2-positive and nestin-negative (Ogawa et al., 2006; Zhao et al., 2007). Combined with previous findings, therefore, our observations imply that Runx 2 might be involved in the formation of bone-like tissues in reparative dentin.

In conclusion, the continuous expression of Runx2 in odontoblasts disturbed odontoblast differentiation at a late stage and resulted in the formation of a bone structure. Runx 2 down-regulated odontoblast-specific proteins, nestin and DSPP, but induced osteopontin and DMP1, indicating that Runx2 induced the transdifferentiation of odontoblasts into osteoblasts. Thus, our findings indicate that Runx2 expression has to be down-regulated during odontoblast differentiation to maintain the phenotype of odontoblasts and acquire full odontoblast differentiation for dentinogenesis.

\section{References}

Aberg T, Wang X-P, Kim J-H, Yamashiro T, Bei M, Rice R, Ryoo H-M, Thesleff I: Runx2 mediates FGF signaling from epithelium to mesenchyme during tooth mophogenesis. Dev Biol 270: 76-93 (2004).

About I, Laurent-Maquin D, Lendahl U, Mitsiadis TA: Nestin expression in embryonic and adult human teeth under normal and pathological conditions. Am J Pathol 157: 287-295 (2000).

Aguiar MC, Arana-Chavez VE: Ultrastructural and immunocytochemical analysis of osteopontin in reactionary and reparative dentine formed after extrusion of upper rat incisors. J Anat 210: 418-427 (2007).

Almushayt A, Narayanan K, Zaki AE, George A: Dentin matrix protein 1 induces cytodifferentiation of dental pulp stem cells into odontoblasts. Gene Ther 13: 611620 (2006).

Aran-Chavez VE, Massa LF: Odontoblasts: the cells forming and maintaining dentine. Int J Biochem Cell Biol 36: 1367-1373 (2004).

Begue-Kirn C, Krebsbach PH, Bartlett JD, Butler WT: Dentin sialoprotein, dentin phosphoprotein, enamelysin and ameloblastin: tooth-specific molecules that are distinctively expressed during murine dental differentiation. Eur J Oral Sci 106: 963-970 (1998).

Braut A, Kollar EJ, Mina M: Analysis of the odontogenic and osteogenic potentials of dental pulp in vivo using a Col1a1-2.3-GFP transgene. Int J Dev Biol 47: 281-292 (2003).

Bronckers ALJJ, Engelse MA, Cavender A, Gaikwad J, D'Souza RN: Cell-specific patterns of Cbfa1 mRNA and protein expression in postnatal murine dental tissues. Mech Dev 101: 255-258 (2001).

Butler WT and Ritchie H: The nature and functional significance of dentin extracellular matrix proteins. Int J Dev Biol 39: 169-179 (1995).

Camilleri S and McDonald F: Runx 2 and dental development. Eur J Oral Sci 114: 361-373 (2006).

Chen S, Rani S, Wu Y, Unterbrink A, Gu TT, GluhakHeinrich J, Chuang H-H, MacDougall M: Differential Regulation of dentin sialophosphoprotein expression by Runx2 during odontoblasts cytodifferentiation. J Biol Chem 280: 29717-29727 (2005).

D'Souza RN, Cavender A, Sunavala G, Alvarez J, Oshima T, Kulkarni AB, MacDougall M: Gene expression patterns of murine dentin matrix protein 1 (Dmp1) and dentin sialophosphoprotein (DSPP) suggest distinct developmental functions in vivo. J Bone Miner Res 12: 2040-2049 (1997).

D'Souza RN, Aberg T, Gaikwad J, Cavender A, Owen M, Karsenty G, Thesleff I: Cbfal is required for epithelialmesenchymal interactions regulating tooth development in mice. Development 126: 2911-2920 (1999).

Gaikwad JS, Hoffmann M, Cavender A, Bronckers ALJJ, D'Souza RN: Molecular insights into the lineagespecific determination of odontoblasts: the role of Cbfal. Adv Dent Res 15: 19-24 (2001).

Geoffroy V, Kneissel M, Fournier B, Boyde A, Matthias P: High bone resorption in adult aging transgenic mice overexpressing Cbfa1/Runx2 in cells of the osteoblastic lineage. Mol Cell Biol 22: 6222-6233 (2002).

Inada M, Yasui T, Nomura S, Miyake S, Deguchi K, Himeno M, Sato M, Yamagiwa H, Kimura T, Yasui N, Ochi T, Endo N, Kitmura Y, Kishimoto T, Komori T: Maturational disturbance of chondrocytes in Cbfaldeficient mice. Dev Dyn 214: 279-290 (1999).

Jiang H, Sodek J, Karsenty G, Thomas H, Ranly D, Chen $\mathrm{J}$ : Expression of core binding factor Osf $2 / \mathrm{Cbfa}-1$ and bone sialoprotein in tooth development. Mech Develop 81: 169-173 (1999).

Kanatani N, Fujita T, Fukuyama R, Liu W, Yoshida CA, Moriishi T, Yamana K, Miyazaki T, Toyosawa S, Komori T: Cbf $\beta$ regulates Runx2 function isoformdependency in postnatal bone development. Dev Biol 296: 48-61 (2006). 
Komori T, Yagi H, Nomura S, Yamaguchi A, Sasaki K, Deguchi K, Shimizu Y, Bronson RT, Gao Y-H, Inada M, Sato M, Okamoto R, Kitamura Y, Yoshiki S, Kishimoto T: Targeted disruption of Cbfal results in a complete lack of bone formation owing to maturational arrest of osteoblasts. Cell 89: 755-764 (1997).

Kusuzaki K, Kageyama N, Shinjo H, Murata H, Takeshita H, Ashihara T, Hirasawa Y: A staining method for bone canaliculi. Acta Orthop Scand 66: 166-168 (1995).

Linde A, Goldberg M: Dentinogenesis. Crit Rev Oral Biol Med 4: 679-728 (1993).

Liu W, Toyosawa S, Furuichi T, Kanatani N, Yoshida C, Liu Y, Himeno M, Narai S, Yamaguchi A, Komori $\mathrm{T}$ : Overexpression of Cbfa1 in osteoblasts inhibits osteoblast maturation and causes osteopenia with multiple fractures. J Cell Biol 155: 157-166 (2001).

Maruyama Z, Yoshida C.A., Furuichi T, Amizuka N, Ito M, Fukuyama R, Miyazaki T, Kitaura H, Nakamura K, Fujita T, Kanatani N, Moriishi T, Yamana K, Liu W, Kawaguchi H, Nakamura K, Komori T: Runx2 determines bone maturity and turnover rate in postnatal bone development and is involved in bone loss in estrogen deficiency. Dev Dyn 236: 1876-1890 (2007).

Mei YF, Yamaza T, Atsuta I, Danjo A, Yamashita Y, Kido MA, Goto M, Akamine A, Tanaka T: Sequential expression of endothelial nitric oxide synthase, inducible nitric oxide synthase, and nitrotyrosine in odontoblasts and pulp cells during dentin repair after tooth preparation in rat molars. Cell Tissue Res 328: 117-127 (2007).

Ogawa R, Saito C, Jung H-S, Oshima H: Capacity of dental pulp differentiation after tooth transplantation. Cell Tissue Res 326: 715-724 (2006).

Otto F, Thornell AP, Crompton T, Denzel A, Gilmour KC, Rosewell IR, Stamp GW, Beddington RS, Mundlos S, Olsen BR, Selby PB, Owen MJ: Cbfa1, a candidate gene for cleidocranial dysplasia syndrome, is essential for osteoblast differentiation and bone development. Cell 89: 677-680 (1997).

Rossert J, Eberspaecher H, de Crombrugghe B: Separate cis-acting DNA elements of the mouse pro- $a 1$ (I) collagen promoter direct expression of reporter genes to different typeI collagen-produsing cells in transgenic mice. J Cell Biol 129: 1421-1432 (1995).

Smith AJ, Cassidy N, Perry H, Bègue-Kirn C, Ruch J-V, Lesot H: Reactionary dentinogenesis. Int J Dev Biol 39: 273-280 (1995).
Sreenath T, Thyagarajan T, Hall B, Longenecker G, D'Souza R, Hong S, Wright JT, MacDougall M, Sauk J, Kulkarni AB: Dentin sialophosphoprotein knockout mouse teeth display widened predentin zone and develop defective dentin mineralization similar to human dentinogenesis imperfecta type III. J Biol Chem 278: 24874-24880 (2003).

Struys T, Krage T, Vandenabeele F, Raab WH-M, Lambrichts: Immunohistochemical evidence for proteolipid protein and nestin expression in the late bell stage of developing rodent teeth. Arch Oral Biol 50: 171-174 (2005).

Terling C, Rass A, Mitsiadis TA, Fried K, Lendahl U, Wroblewski J: Expression of the intermediate filament nestin during rodent tooth development. Int J Dev Biol 39: 947-956 (1995).

Toyosawa S, Shintani S, Fujiwara T, Ooshima T, Sato A, Ijuin N, Komori T: Dentin matrix protein 1 is predominantly expressed in chicken and rat osteocytes but not in osteoblasts. J Bone Miner Res 16: 2017-2026 (2001).

Toyosawa S, Okabayashi K, Komori T, Ijuhin N: mRNA expression and protein localization of dentin matrix protein 1 during dental root formation. Bone 34: 124133 (2004).

Tziafas D: Basic mechanisms of cytodifferentiation and dentinogenesis during dental pulp repair. Int J Dev Biol 39: 281-290 (1995).

Ueta C, Iwamoto M, Kanatani N, Yoshida C, Liu Y, Enomot-Iwamoto M, Ohmori T, Enomoto H, Nakata K, Takada, K, Kurisu K, Komori T: Skeltal malformations caused by overexpression of Cbfa1 or its dominant negative form in chondrocytes. J Cell Biol 153: 87-99 (2001).

Yamashiro T, Aberg T, Levanon D, Groner Y, Thesleff I: Expression of Runx1, -2 and -3 during tooth, palate and craniofacial bone development. Mech Dev 119S: S107S1 10 (2002).

Zhao C, Hosoya A, Kurita H, Hu T, Hiraga T, Ninomiya T, Yoshiba K, Yoshiba N, Takahashi M, Kurashina K, Ozawa H, Nakamura H: Immunohistochemical study of hard tissue formation in the rat pulp cavity after tooth replantation. Arch Oral Biol 52: 945-953 (2007). 